\title{
Three-year' experience of a tertiary level occupational diseases clinic
}

\author{
Arif ÇIMRIN $\mathbf{1}_{(\mathrm{ID})}$ \\ Yücel DEMIRAL ${ }^{2}(I D)$ \\ Nur Şafak ALICI ${ }^{3 !}(\overline{I I D}) !$ \\ Ayşe COŞKUN BĒYĀ N
}

Cite this arcticle as: Çımrın A, Demiral Y, Alıcı NŞ, Coşkun Beyan A. Three-year' experience of a tertiary level occupational diseases clinic. Tuberk Toraks 2019;67(4):285-91.

\section{Yazışma Adresi (Address for Correspondence)}

\section{Dr. Nur Şafak ALICI}

İzmir Dr. Suat Seren Göğüs Hastalıkları ve Cerrahisi Eğitim ve Araştırma Hastanesi, Meslek Hastalıkları Kliniği, IZMIR - TÜRKIYE

e-mail: safak.alici@hotmail.com

CCopyright 2019 by Tuberculosis and Thorax.

Available on-line at www.tuberktoraks.org.com
${ }^{1}$ Department of Chest Diseases, Faculty of Medicine, Dokuz Eylul University, Izmir, Turkey

${ }^{1}$ Dokuz Eylül Üniversitesi Tıp Fakültesi, Göğ̈̈s Hastalıkları Anabilim Dalı, Izmir, Türkiye

${ }^{2}$ Department of Public Health, Faculty of Medicine, Dokuz Eylul University, Izmir, Turkey

${ }^{2}$ Dokuz Eylül Üniversitesi Tıp Fakültesi, Halk Sağlığı Anabilim Dalı, İzmir, Türkiye

${ }^{3}$ Clinic of Occupational Diseases, Izmir Dr. Suat Seren Chest Diseases and Surgery Training and Research Hospital, Izmir, Turkey

${ }^{3}$ Izmir Dr. Suat Seren Gögüus Hastalıkları ve Cerrahisi Ĕgitim ve Araştırma Hastanesi, Meslek Hastalıkları Kliniği, İzmir, Türkiye

${ }^{4}$ Department of Occupational Diseases, Faculty of Medicine, Dokuz Eylul University, Izmir, Turkey

${ }^{4}$ Dokuz Eylül Üniversitesi Tıp Fakültesi, Meslek Hastalıkları Anabilim Dalı, izmir, Türkiye

\section{ABSTRACT}

Three-year' experience of a tertiary level occupational diseases clinic

Introduction: We aimed to evaluate the diagnosis of patients who applied on the first three years of our clinic, in order to contribute to the state of occupational diseases (OD) in Turkey.

Materials and Methods: The study is a cross-sectional study, between November 2013 and December 2016, 862 subjects were accepted for the evaluation. Gender, age, application ways, the reason of referral, workplace, exposure time and possible risks for the patients were evaluated through a file examination.

Results: Total of $708(82.1 \%)$ was male and $154(17.9 \%)$ were female. The mean age of the subjects was $38.3 \pm 7.7$ years; the mean term of employment was $126.6 \pm 87.3(1-420)$ months. The most common cause of referral was the suspicion of occupational pulmonary diseases (64.3\%) with 554 workers. 435 workers $(50,6 \%)$ were diagnosed to have an OD, 78 workers $(9.0 \%)$ were diagnosed with work-related diseases. The most common diagnoses of OD; 169 (38.9\%) pneumoconiosis, 71 (16.3\%) occupational asthma, 38 (8.7\%) cervical disc hernia, 24 (5.5\%) lumbar disc hernia, 24 (5.5\%) hearing loss, 19 (4.3\%) cubital/carpal tunnel, and 15 (3.4\%) workers have lead intoxication. 
Conclusion: Dust, chemicals, ergonomic risks and noise still remain as important occupational health risks in Turkey. It is seen that the existing occupational diseases monitoring system is inadequate to identify and manage the health problems of the workers. An effective and comprehensive occupational disease monitoring system should be established and legal regulations should be planned.

Key words: Pneumoconiosis; occupational diseases; occupational pulmonary diseases; occupational asthma

\section{ÖZ}

\section{Üç yıllık meslek hastalıkları kliniği deneyimi}

Giriş: Türkiye'deki meslek hastalıklarının durumuna katkıda bulunmak amacı ile kliniğimizin ilk üç yılında başvuran hastaların tanılarının değerlendirilmesi amaçlanmıştır.

Materyal ve Metod: Çalışma kesitsel bir çalışmadır. Kasım 2013-Aralık 2016 tarihleri arasında başvuran 862 olgunun tamamı çalışmaya alınmıştır. Olguların cinsiyet, yaş, başvuru şekilleri, sevk eden kurumlar, sevk nedeni, çalıştı̆̆ı işyeri, maruz kalım süresi, maruz kaldıkları olası riskler ve son tanıları değerlendirilmiştir.

Bulgular: Toplam 862 olgu çalışmaya alındı. Bu olgulardan 708 (\%82.1)'i erkek, 154 (\% 17.9)'ü kadındı. Olguların yaş ortalaması $38.3 \pm 7.7$ yıl idi. Çalışma süreleri ortalama $126.6 \pm 87.3$ (1-420) aydı. En sık başvuru nedeni, 554 (\%64.3) olgu ile mesleksel solunum sistemi hastalığı şüphesi idi. 435 (\%50.6) olguya meslek hastalı̆̆ı, 78 (\%9.0) olguya işin şiddetlendirdiği hastalık tanısı konuldu. En sık tanı konulan meslek hastalıkları; 169 (\%38.9) olgu pnömokonyoz, 71 (\% 16.3) olgu mesleksel astım, 38 (\% 8.7) olgu servikal disk hernisi, 24 (\%5.5) olgu lomber disk hernisi, 24 (\%5.5) olgu işitme kaybı, 19 (\%4.3) olgu kubital/karpal tünel, 15 (\%3.4) olgu kurşun intoksikasyonu tanılarıydı.

Sonuç: Toz, kimyasallar, ergonomik riskler ve gürültü, Türkiye'de hala önemli iş sağlığı riski olarak kalmaktadır. Mevcut meslek hastaIıkları izleme sisteminin, çalışanların sağlık sorunlarını tanımlamak ve yönetmek için yetersiz olduğu görülmektedir. Etkili ve kapsamlı bir mesleki hastalık izleme sistemi kurulmalı ve yasal düzenlemeler planlanmalıdır.

Anahtar kelimeler: Pnömokonyoz; meslek hastalıkları; mesleki akciğer hastalıkları; mesleki astım

\section{INTRODUCTION}

One of the important parameters indicating the status of the occupational health profile in a country is the number of occupational diseases (OD) registered in the country. Prevention is key since it not only protects the lives and livelihoods of workers and their families but also contributes to ensuring economic, ethical and social development. The collection, recording and notification of data on OD are crucial for development of prevention strategies and set the priorities. It is also important to analyze and study their causes in order to develop preventive measures (1). Reported disease statistics are often incomplete, since under-reporting is common, and official reporting requirements frequently do not cover all categories of workers in the world (2).

In Turkey, according to the Occupational Safety and Health Law (No 6331, 2012), the employer have to keep a list of occupational diseases and shall notify the Social Security Institution. Occupational physicians or health care providers shall refer workers with pre-diagnosis of occupational diseases to health care providers authorized by the Social Security Institution. These authorized health care providers shall notify the Social Security Institution within 10 days when diagnosis of occupational disease is confirmed. According to Law, the occupational physician (OP) and occupational safety specialist are responsible for conducting health and safety services on behalf of the employer in the workplace. Any physician working at a health care provider organization (occupational physician, primary care physician, hospital physician, etc.) can report the case to the Social Security Institution via the authorized hospitals. Even a person (working or retired) can directly apply to the Institution with the claim of an occupational disease. This application is conveyed to one of the authorized hospitals for evaluation. The compensation issues are the right and responsibility of the Social Security Institution.

The Ministry of Family, Labor and Social Services is the main responsible organization in occupational health field, in collaboration with other ministries and stakeholders, and is responsible for developing, implementing and enforcing legislation. According to Law 6631: Providing occupational safety and health services is the responsibility of the employer. According to the Turkish statistical institute, Turkey's working age population of 15-65 years in 2016 was 58 million of those 27 million are employed (3). 19.0\% were employed in agriculture, $19.6 \%$ in industry, $7.1 \%$ in construction and $54.4 \%$ in the service sector (4). As of August 2016, the number of compulsory insured 
(under the Article 4-1/of Law no. 5510) population was reported as 15.5 million (5). It was reported that $2.1 \%$ (about 500.000 people) of the employed or those who have worked in the past had a reported work-related health problem in the past 12 months. When the distribution of these problems were considered, musculoskeletal problems were $53.2 \%$; stress, depression or anxiety problems were $20.0 \%$; respiratory or lung problems were $5.8 \%$; skin problems were $2.1 \%$; hearing problems were $1.0 \%$; a headache or eye fatigue was $3.9 \%$; problems related to the heart related or circulatory system were $2.7 \%$; infectious disease (viruses, bacteria or other types of infections) $1.0 \%$; gastrointestinal problems related to liver, kidney or digestive tract were $3.5 \%$, and other complaints were $2.7 \%$ (6).

Given the fact that the incidence of occupational diseases in working population ranges between 4 and 12 per thousand according to the estimation of International Labour Organization (ILO), it can be expected that 100.000 to 300.000 workers suffer from an occupational disease annually in Turkey. National Occupational Health and Safety Policy Document covering the period between 2009 and 2013 indicates that the occupational diseases could not be recognized $(7,8)$.

There is no statistical data published by the Ministry of Health about ODs in our country. The SSI does not reflect the cases outside the cases which are entitled to compensation by evaluating them in their authorized boards to ODs statistics.

By the reason of the limitations on the diagnosis of ODs in our country, the Ministry of Health defined the field of specialization of ODs in 2014. 12 subbranch specialists have graduated so far. Occupational diseases applications are evaluated by a total of 10 institutions (9). Our unit is the first tertiary institution that evaluates patients referred by a physcians or SSI for diagnosis of occupational diseases. Three of ten hospitals are Occupational Disease Hospital which established in 1970s. 3388 of a total of 6,792 cases were diagnosed with ODs in 2008 in the three ODs hospital. In 2011, a total of 12.000 people applied to the ODs hospitals (10).

This research aims to share three years' experience as a tertiary hospital authorized to diagnose OD and to provide information on the occupational diseases diagnosis and notification system in Turkey.

\section{MATERIALS and METHODS}

The study is a cross-sectional study. All of the 862 cases referred between November 2013, and December 2016 were evaluated. The cases were assessed by gender, age, the application form, referring institutions, referral cause, workplace, exposure duration and possible risks of exposure via file examinations.

Diseases in which a cause-effect, effect-response relationship could be demonstrated between a harmful agent and the affected human body in the job being done were defined as "occupational diseases"; even though many causal factors and other risk factors present in the workplace play a role together, even if they do not originate directly from the workplace, the diseases that were affected by the factors in the workplace and whose conditions changed were defined as "the disease exacerbated by the work" (11). The diagnosis of the occupational disease was done by ILO criteria's (2) .

The data obtained were presented as frequency and percentage distributions. PASW Statistics for Windows Package Statistical Program (SPSS Inc. Version 18.0, Chicago, USA) was used to evaluate the data.

\section{RESULTS}

There were a 862 patients of those $708(82.1 \%)$ were male, and $154(17.9 \%)$ were female during the study period. The mean age of the cases was $38.3 \pm 7.7$; the youngest was 21 , and the eldest was 76 years old. The mean duration of work was $126.6 \pm 87.3(1-420)$ months. Two hundred and fifty patients $(29 \%)$ never smoked, $362(42 \%)$ were smoking and $249(28.8 \%)$ patients quit smoking. Average package year was $10.5 \pm 10.5$ (0-60).

Table 1 summarizes the jobs and sectors of the cases. The majority of the sectors were mining, ceramics, metal, dental technician, machinery, furniture, chemistry, textile-leather, electrical-electronics, service and health sectors. Cases classified as "others" in Table 1 were the lines of work such as animator, health technician, bakery worker, and archivist. According to the work and exposure history of the cases, they were found to be exposed to many risk factors. The most common exposures were; the dust/ metal dust-smoke 399 (46.3\%), ergonomic 214 (24.8\%), chemical $195(22.6 \%)$ and noise $26(3.0 \%)$ (Table 2). 
Three-year' experience of a tertiary level occupational diseases clinic

\section{Table 1. The sectors and the work done by the cases}

\begin{tabular}{|c|c|c|}
\hline Sector & Work & n $(\%)$ \\
\hline \multirow[t]{3}{*}{ Mine-Marble } & Coal and metal ore mining & $26(3.0 \%)$ \\
\hline & Stone crusher operator & $16(1.9 \%)$ \\
\hline & Marble-Cimstone cutting & $10(1.1 \%)$ \\
\hline Ceramic & Ceramic/vitreous worker & $144(16.7 \%)$ \\
\hline \multirow[t]{5}{*}{ Metal } & Molding & $30(3.5 \%)$ \\
\hline & Welding & $48(5.6 \%)$ \\
\hline & Metal grinding-sanding & $16(1.8 \%)$ \\
\hline & Lathe leveling/CNC & $11(1.2 \%)$ \\
\hline & Rolling mill & $3(0.3 \%)$ \\
\hline Dental technician & Dental technician & $75(8.7 \%)$ \\
\hline Sandblasting & Jeans/metal/glass sanding & $20(2.3 \%)$ \\
\hline \multirow[t]{2}{*}{ Machinery } & Mechanical maintenance & $21(2.4 \%)$ \\
\hline & Printing press & $9(1.04 \%)$ \\
\hline Furniture & Furniture manufacturing, painting and polishing & $16(1.8 \%)$ \\
\hline \multirow[t]{4}{*}{ Chemistry } & Manufacture of chemical products & $20(2.3 \%)$ \\
\hline & Lead/nickel worker & $10(1.1 \%)$ \\
\hline & Plastic injection/cutting operator & $23(2.6 \%)$ \\
\hline & Painting (auto/furniture/metal) & $33(3.8 \%)$ \\
\hline \multirow[t]{2}{*}{ Textile, Leather } & Textile product cutting-sewing & $27(3.1 \%)$ \\
\hline & Leather tanning-cutting-gluing & $7(0.8 \%)$ \\
\hline Electric-electronic & Electronic assembly worker & $88(10.2 \%)$ \\
\hline \multirow[t]{3}{*}{ Service } & Call center operator & $11(1.3 \%)$ \\
\hline & Cleaning & $33(3.8 \%)$ \\
\hline & Warehouse transport worker-porter & $32(3.71 \%)$ \\
\hline \multirow[t]{2}{*}{ Healthcare workers } & Nurse & $17(2.0 \%)$ \\
\hline & Laboratory staff & $8(0.9 \%)$ \\
\hline Other & & $108(12.5 \%)$ \\
\hline Total & & $862(100 \%)$ \\
\hline
\end{tabular}

Distribution of the cases according to the referring institutions were as follows; 328 cases $(38.1 \%)$ were referred from SSI, 282 cases $(32.7 \%)$ from occupational physicians, 248 cases $(28.8 \%)$ from the specialist physicians of the secondary and tertiary care state hospitals and 4 cases $(0.5 \%)$ from Labor Lourt. The most common reason for referral was the suspicion of an occupational respiratory disease. A total of 36 cases $(4.2 \%)$ with 13 pneumoconiosis $(36.1 \%)$ were referred second time for clinical control (Table 3).

Eight hundred and eleven (94.1\%) case evaluations were completed. The remaining 51 (5.9\%) cases were under evaluation. No disease or occupational relationship were detected in 224 (25\%) of the completed cases. 435 cases diagnosed as occupational diseases and 78 cases diagnosed as the disease exacerbated by the work. Communication was interrupted with 74 cases. So we couldn't evaluate them. The most common OD diagnoses were; pneumoconiosis $(\mathrm{n}=169,38.9 \%)$, occupational asthma $(\mathrm{n}=71$, $6.3 \%)$, cervical disc hernia $(n=38,8.7 \%)$, lumbar disc hernia $(n=24,5.5 \%)$, hearing loss $(n=24$, $5.5 \%)$, cubital/carpal tunnel syndrome $(n=19,4.3 \%)$ and lead intoxication ( $n=15,3.4 \%$ ) (Table 4$)$.

Distribution of the cases, when assessed according to ILO classification of occupational diseases, was as 


\section{Table 2. The main risks factors}

\begin{tabular}{|lc|}
\hline Risk & n (\%) \\
\hline Dust & $323(37.5)$ \\
Ergonomic & $214(24.8)$ \\
Chemical & $195(22.6)$ \\
Metal dust/smoke & $76(8.8)$ \\
Noise & $26(3.0)$ \\
Biologic/allergen & $18(2.1)$ \\
Psychosocial & $6(0.6)$ \\
Non-ionizing radiation & $3(0.3)$ \\
Other physical (cold) & $1(0.1)$ \\
Total & 862 \\
\hline
\end{tabular}

Table 3. Referral reasons of cases

\begin{tabular}{|lc|}
\hline Referral reason & n (\%) \\
\hline Respiratory system disease & $554(64.3)$ \\
Musculoskeletal system disease & $197(22.9)$ \\
Dermatologic disease & $28(3.2)$ \\
Otolaryngologic disease & $29(3.4)$ \\
Toxic effect (lead, solvent) & $26(3.0)$ \\
Neurological disease & $7(0.8)$ \\
Other & $21(2.4)$ \\
Total & 862 \\
\hline
\end{tabular}

Table 4. Distribution of occupational disease diagnoses

\begin{tabular}{|c|c|c|c|c|c|c|c|}
\hline System & Disease & $N=435$ & $\%$ & System & Disease & $N=435$ & $\%$ \\
\hline \multirow[t]{6}{*}{$\begin{array}{l}\text { Respiratory } \\
\text { system }\end{array}$} & $\begin{array}{l}\text { Pneumoconiosis/welder } \\
\text { lung }\end{array}$ & 169 & 38.9 & Dermatology & Allergic CD & 11 & 2.5 \\
\hline & Occupational asthma & 71 & 16.3 & & Irritant CD & 3 & 0.7 \\
\hline & COPD/Chronic bronchitis & 7 & 1.6 & Otolaryngology & Hearing loss & 24 & 5.5 \\
\hline & $\begin{array}{l}\text { Pleural/mediastinal } \\
\text { pathology }\end{array}$ & 4 & 0.9 & $\begin{array}{l}\text { Systemic } \\
\text { intoxications }\end{array}$ & Lead intox & 15 & 3.4 \\
\hline & $\begin{array}{l}\text { RADS/DAH/DIP/Metal } \\
\text { fume fever/chemical } \\
\text { pneumonitis }\end{array}$ & 13 & 2.9 & & Glycoasetate intox & 2 & 0.5 \\
\hline & Tuberculosis & 1 & 0.2 & & Perchloroethylene & 1 & 0.2 \\
\hline \multirow[t]{5}{*}{$\begin{array}{l}\text { Musculoskeletal } \\
\text { system }\end{array}$} & $\begin{array}{l}\text { Cervical disc herniation } \\
(\mathrm{CDH})\end{array}$ & 38 & 8.7 & Neurologic & Polyneuropathy & 3 & 0.7 \\
\hline & $\begin{array}{l}\text { Lumbar disc herniation } \\
(\mathrm{LDH})\end{array}$ & 24 & 5.5 & Psychiatric & Algoneurodystrophy & 1 & 0.2 \\
\hline & Carpal/cubital tunnel & 19 & 4.3 & Hematologic & MDS & 1 & 0.2 \\
\hline & $\begin{array}{l}\text { Epicondylitis/tendonitis/ } \\
\text { meniscopathy/other }\end{array}$ & 12 & 1.8 & Hepatic system & Toxic hepatitis & 1 & 0.2 \\
\hline & $\begin{array}{l}\text { Thoracic disc herniation } \\
(\mathrm{TDH})\end{array}$ & 2 & 0.5 & $\begin{array}{l}\text { Other } \\
\text { (eye, genitourinary, } \\
\text { rheumatology...) }\end{array}$ & & 13 & 1.8 \\
\hline
\end{tabular}

following; 262 cases (30.4\%) had respiratory system diseases, 10 cases $(12.8 \%)$ musculoskeletal system diseases, 23 cases $(2.7 \%)$ diseases related to chemicals, $22(2.6 \%)$ diseases related to physical conditions and $14(1.6 \%)$ cases skin diseases.

Distribution of the cases according to the OD list used in Turkey was as following; 262 cases (30.4\%) had pneumoconiosis and other respiratory system diseases, 132 cases (15.3\%) OD related to physical conditions, 23 cases ( $2.7 \%$ ) OD related to chemicals, 14 cases $(1.6 \%)$ occupational skin diseases and 1 case $(0.1 \%)$ occupational infectious disease.

\section{DISCUSSION}

Our data emphasize that the generalization of the similar units could be a significant development in overcoming the limitations associated with the surveil- 
lance of ODs in Turkey, and the health organization associated with OHS. According to the reported figures, $435(50.4 \%)$ out of 862 referred cases were diagnosed as OD in our outpatient clinic. Occupational diseases hospitals were diagnosed with occupational diseases at a similar rate $(40-60 \%)$ to our clinic. On the other hand, the cases that applied to our clinic only represent the registered employees. There is a high unregistered employment rate $(30-40 \%)$ in our country, also it is important that workers in small-scale workplaces employing less than 50 employees, whose OHS services are inadequate, might be excluded from adequate OHS practices (12). But, the figures published by the SSI on the same dates are around 500 (13). This major gap suggests that there are significant problems with the diagnosis and notification of ODs.

When the distribution of the diagnoses of our cases evaluated, leading known ODs (pneumoconiosis, asthma, musculoskeletal system problems, dermatitis and hearing loss related to noise) were observed. The distribution of ODs in our cases shows that the classical occupational risks which consist of dust, noise, ergonomic risk and chemicals in our country are still not fully controlled and that cases with psychosocial problems cannot be detected in the workplace. ILO also highlighted pneumoconiosis epidemic. China reported a total of 27.240 cases of occupational diseases, including 23.812 caused by exposure to workplace dusts in 2010 (14). In the same year, 22.013 cases of occupational diseases were reported in Argentina, with musculoskeletal disorders (MSDs) and respiratory diseases among the most frequent diseases. Japan reported a total of 7779 cases of occupational diseases mainly related to low-back disorders and pneumoconiosis. The distribution by diagnosis differs from the ODs associated with leading psychosocial and musculoskeletal systems in industrialized countries (1). In our country, it is seen that there is a problem about the diagnosis of psychosocial and ergonomics risks. ILO screening for dusty workplaces is considered to be the most important factor in the high rate of pneumoconiosis diagnosis.

In Turkey, there is no OD surveillance system fitting the recommendations of the ILO based on protection and prevention. According to ILO, the primary target of an OD registration and notification system should be to use them in implementing preventive measures for OD. In Turkey, occupational diseases data only kept on insurance records. It is not reflecting the actual number of occupational diseases so there is no development for protection measures.

In their study by Spreeuwers et al. comparing the occupational diseases registration and notification systems in $6 \mathrm{EU}$ countries, Austria, Belgium and France, which only collect data for the provision of insurance services, stated that preventive services are insufficient in occupational health services. They stated that recording, monitoring and preventive activities are better provided in the registration systems for the planning of preventive activities such as Finland and England and for scientific research (15). Tang et al analyzed OD reporting system benefits and find out very striking results in their study. According to authors: the benefit of occupational disease reporting system depends on the cost-benefit of occupational disease prevention and control measures. The results of the decision tree analysis showed that when an occupational disease monitoring system was established, the incremental input for occupational disease monitoring and prevention/control was 2.1 billion yuan/year, the output was 6.5 billion yuan/ year, and the benefit of occupational disease reporting system was 4.4 billion yuan/year (16).

Another important effect of the absence of OD monitoring system was on job security. Because of the social and economic aspects the workers diagnosed OD are not only encounter with medical problems but also social, economic, legal and psychological problems during the process of the diagnosis, treatment, and returning to work. Issues related to the job security such as workplace pressure, fear of being fired from work seem to be important. In our clinic, $33.3 \%$ of patients with the diagnosis of pneumoconiosis dismissed or left their jobs either while the evaluation process was in progress or after the diagnosis was made. We have found that $4.4 \%$ of these cases were dismissed/left their jobs immediately after the application to our clinic $(17,18)$. Policies and regulations should account for the risk of unemployment after OD diagnosis. OD surveillance systems should obtain data on the employment status of the workers after diagnoses, and reports in the workplace should be intended to monitor worker health and well-being.

As a general, chemicals, ergonomic risks and noise still remain as important occupational health risks in Turkey. This alone is an indication of the inadequacy of OHS implementations in workplaces as well as the 
presence of dirty industries. Training studies that enhance the competencies of workplace physicians seem important. Generalization of OHS centers similar to our clinic as well as ODs hospitals will strengthen the effectiveness of OHS activities in the workplace.

There are some limitations in our research. All data of the authorized centers for the diagnosis of occupational disease in Turkey is unknown. Therefore, no comment could be made about the diagnosis of occupational diseases in other centers. Our center is a referral center which workers from Aegean region referred. So our results could be affected from the regional workplace properties. Regional differences may not reflect Turkey's profile.

In conclusion, to define and manage the health problems of employees is essential to activate health surveillance in workplaces and to establish the legal infrastructure. First of all, different institutions in health system have a role and responsibility in Turkey. Priority should be given to the establishment of a national, autonomous occupational health institution for the revision of the occupational health system and the planning of policies and the provision of services as a whole.

\section{CONFLICT of INTEREST}

There is no conflict of interest related to this study.

\section{AUTHORSHIP CONTRIBUTIONS}

Concept/Design: All of authors.

Analysis/Interpretation: All of authors.

Data Acquisition: All of authors.

Written by: All of authors.

Critical Revision: All of authors.

Final Approval: All of authors.

\section{REFERENCES}

1. International Labour Office (ILO). The prevention of occupational diseases. 2013 avaible from https://www.ilo.org/ safework/info/WCMS_208226/lang--en/index.htm.

2. International Labour Office.Identification and recognition ofoccupationaldiseases:Criteria for incorporating diseases in the ILO list of occupational diseases. Meeting of Experts on the Revision of the List of Occupational Diseases (Recommendation No. 194).

3. Turkish Statistical Institute. Labor Force Statistics, Ocaknisan 2016. Sayı: 21570. avaible from http://www.tuik. gov.tr/PreHaberBultenleri.do?id=21570.
4. Turkish Statistical Institute (TUIK) News Bulletin Issue 21571, June 15, 2016. avaible from: http://www.tuik.gov. tr/PreHaberBultenleri.do?id=21571.

5. Social Security institution Statistical Annals 2016. available from http://www.sgk.gov.tr/wps/portal/sgk/tr/kurumsal/istatistik/sgk_istatistik_yilliklari.

6. Work accidents and work-related health problems research results 2013. Turkish Statistical Institute (TUIK) department of labour force and ve life conditions January 2014 Avaible from http://www.tuik.gov.tr/jsp/duyuru/ upload/yayinrapor/2013_ISKAZALARI_VE.

7. T.C. Aile, Çalışma ve Sosyal Hizmetler Bakanlığı. Ulusal iş Sağ/ığı ve Güvenliği Politika Belgesi avaible from https:// www.ailevecalisma.gov.tr/isggm. 2015.

8. T.C.Aile, Çalışma ve Sosyal Hizmetler BakanlığıUlusal iş Sağ/ığı ve Güvenliği Politika Belgesi avaible from https:// www.ailevecalisma.gov.tr/isggm. 2009.

9. İş ve meslek hastalıkları uzmanları derneği (IMUD). Bülten 2018 avaible from http://imud.org.tr/BULTEN. html.

10. Meslek hastalıkları yuvarlak masa toplantısı. Mesleki Sağlık Güvenlik Dergisi 2014;14:51-52. avaible from http:// www.ttb.org.tr/dergi/index.php/msg/issue/view/20/ showToc. 51-52, 2014.

11. Occupational Diseases and Work Related Diseases Diagnosis Guide. Turkish Ministry of Labor and Social Security Publications (2001).

12. Republic of turkey, social security instutions. Unregistered employment rates. avaiable from: http://www.sgk.gov.tr/ wps/portal/sgk/tr/calisan/kayitdisi_istihdam/kayitdisi_istihdam_oranlari/kayitdisi_istihdam_orani.

13. Republic of turkey.Instutions, Social Security. statistics annuals avaiable from: http://www.sgk.gov.tr/wps/portal/ sgk/tr/kurumsal/istatistik/sgk_istatistik_yilliklari.

14. Xueyan Zhang, Zhongxu Wang,Tao Li. The current status of occupational health in China. 5, s.l.: Environ Health Prev Med, 2010, Vol. 15. 263-270.

15. Spreeuwers $D$, de Boer $A G$, Verbeek $J H$, van Dijk $F$. Evaluation of occupational disease surveillance in six EU countries. Occup Med (Lond). 2010;60(7):509-16. doi: 10.1093/occmed/kqq133.

16. Tang XZ, Zeng Q, Liu DS.A cost-benefit analysis of occupational disease reporting in China. Zhonghua Lao Dong Wei Sheng Zhi Ye Bing Za Zhi. 2017 Mar 20;35(3):226229. doi: 10.3760/cma.j.issn.1001-9391.2017.03.019.

17. Coşkun Beyan A, Alici NŞ, Çımrın A. A perspective on occupational musculoskeletal diseases in turkey; case cluster study. I Clin Anal Med 2017;8(Suppl 2):117-20.

18. Alici NS, Beyan A, Çımrın A. social consequences of pneumoconiosis. TORAKS National Congress,2016 poster presentation. 